\title{
Hastanede Yatan 0-6 Yaş Grubu Çocukların Annelerinin Ev Kazaları Konusundaki Bilgi ve Uygulamalarının İncelenmesi
}

\author{
Investigation of Home Accidents Knowledge and Practices of Mothers of 0-6 Age Group \\ Inpatient Children
}

\author{
Ebru ŞEKERCİ ${ }^{\mathrm{a}}$ Sevil İNAL ${ }^{\mathrm{b}}$
}

\begin{abstract}
ÖZET Amaç: Bu araştırma çocuk kliniğinde yatan 0-6 yaş grubu çocukların annelerinin, ev kazaları konusundaki bilgi ve uygulamalarını belirlemek amacı ile tanımlayıcı olarak gerçekleştirildi. Gereç-Yöntem: Araştırma evrenini Ekim-2012 ve Mart-2013 tarihleri arasında, çocuk kliniğinde yatan 0-6 yaş grubu çocuk anneleri, örneklemini ise 0-6 yaş grubu çocuğu olan ve araştırmaya gönüllü olarak katılan toplam 235 anne oluşturdu. Veri toplama aracı olarak araştırmacilar tarafindan literatür doğrultusunda geliştirilen anket formu ile " $0-6$ Yaş Çocuklarda Annenin Ev Kazalarına Yönelik Güvenlik Önlemlerini Tanımlama Ölçeği” kullanıldı. Verilerin değerlendirilmesinde SPSS (Statistical Packagefor Social Sciences) for Windows 20.0 programı, istatistiksel analizlerde ise Shapiro-Wilk testi, Kruskal Wallis testi, Mann-Whitney U testi ve ki-kare testi kullanıldı. Bulgular: Araştırmadan elde edilen verilere göre; araştırma kapsamındaki annelerin yaş ortalamalarının $30( \pm 5,73)$ yıl olduğu, c\%15,7'sinin çalıştı̆̆ \%49,4'ünün eğitim seviyesinin ilkokul ve altı düzeyde olduğu belirlendi. Çalışmadaki çocukların yaş ortalamalarının $24( \pm 21,99)$ ay olduğu, \%30,2’sinin en az bir kez ev kazasına maruz kaldığı belirlendi. Çocuğun ev kazası geçirme sıklığı ile annenin yaşı, çocuğun cinsiyeti arasında istatistiksel olarak anlamlı bir ilişkiye rastlanmadı ( $>>0,05)$. 1-3 yaş grubu çocuklarda ev kazası geçirme sıklığının anlamlı şekilde yüksek olduğu ( $<<0.05)$, meydana gelen ev kazalarında düşmelerin \%55'ile ilk sırada yer aldığı, kazaların büyük çoğunluğunun $(\% 62,5)$ salonda meydana geldiği saptandı. Kazaların \%55'inde annenin kaza sırasında çocuğun yanında olduğu görüldü. Çocuğu daha önce ev kazası geçiren ailelerin \%60'ının kaza sonrası sağlık kuruluşuna başvurduğu, \%36,3'ünün evde önlemler aldığı belirlendi. Anne ve babanın eğitim durumu, aylık gelir durumu, çocuk odası varlığı, çocuğun evdeki uyuma ortamı, yaşına uygun oyuncak seçimi, ev kazaları ve ilk yardım uygulamaları konusunda eğitim alma durumu ile annelerin "0-6 Yaş Çocuklarda Annenin Ev Kazalarına Yönelik Güvenlik Önlemlerini Tanımlama Ölçeği” puan ortalamaları arasında anlamlı bir ilişki olduğu belirlendi $(p<0,05)$. Sonuç: Hemşirelerin hastaneye yatan çocukların ailelerini ev kazaları konusunda eğiterek güvenli ev ortamı sağlamaya yönelik farkındalık düzeylerini arttırması, bu eğitimlerde ailelerin sosyo-kültürel düzeyinin dikkate alınması önerilebilir.
\end{abstract}

Anahtar Kelimeler: Ev kazaları, güvenlik önlemleri, hemşirelik,0-6 yaş çocuk,

ABTRACT Purpose: This research is planned as a descriptive to determine of the knowledge and practices of mothers of aged 0-6 years old inpatient children in pediatry clinics. Methods: The research universe is consisted between October 2012 and March 2013 by the mothers having 0-6 age group children staying in child clinical in Research Hospital; and the sampling is done by universe known group chosen with sampling method with the help of 235 mothers voluntarily accepting to take part in this research. Data was collected using a questionnaire prepared by examining the literature by researchers and "0-6 Year Old Children's Mothers' Identification Scale Security Measures Towards Home Accidents". For data evaluation SPSS (Statistical Packagef Social Sciences) for Windows 20.0 program; for statistical analysis Shapiro-Wilk, Kruskal Wallis, Mann-Whitney U and ki-kare tests are preferred. Results: According to the results, the average age of the participating mothers is $30( \pm 5,73)$ years, $\% 15,7$ of them are employed and \%49,4 of them have elementary or lower school education level. The average age for children was $24( \pm 21,99)$ months and $\% 54,9$ was male. $\% 30,2$ of children who are subject to the research have at

Geliş Tarihi/Received:24-01-2016/ Kabul Tarihi/Accepted:31-05-2016

a Uzman Hemşire, Uludağ Üniversitesi Sağlık Uygulama ve Araştırma Hastanesi Çocuk Kliniği,

e-mail: ebrusekerci@mynet.com

b Doç. Dr. İstanbul Üniversitesi, Sağlı Bilimleri Fakültesi, Ebelik Bölümü

Sorumlu yazar /correspondence: İstanbul Üniversitesi, Sağlık Bilimleri Fakültesi, Ebelik Bölümü, Demirkapı Cad. Karabal Sok. Zuhuratbaba/ Bakırköy /İstanbul, Tel: 02124141500 /40141 e-mail: inalsevil@ gmail.com

$\mathrm{Bu}$ araştırma Haliç Üniversitesi, Çocuk Sağlığı ve Hastalıkları Hemşireliği ABD. Yüksek lisans Tezi olarak yapilmıştır

Atıf: Şekerci E, İnal S. Hastanede Yatan 0-6 Yaş Grubu Çocukların Annelerinin Ev Kazaları Konusundaki Bilgi Ve Uygulamalarının İncelenmesi. HSP 2016;3 (3):160-172.

To cite this article: Şekerci E, İnal S. Investigation of Home Accidents Knowledge and Practices of Mothers of 0-6 Age Group Inpatient Children. HSP 2016;3 (3):160-172 
least once been subject to a home accident. Any statistically meaningful relevance between the occurrence frequency of home accident and mothers' age, or gender of child has not been observed ( $>0,05)$. The majority of the children to have home accident have been observed to be between 1-3 ages (\%56,3). \%55 of the home accident occurring as falls and \%62,5 of them happen in living room of home. After the accident has happened \%60 of all families applied to a health care provider, $\% 36,3$ of mothers took measures about home accidents, The education level of parents, total monthly income, existence of a private room for child, sleeping environment of the child, correct toy selection, first aid and home accidents education of mothers have been observed to have a meaningful relation with mothers' scaling score $(\mathrm{p}<0,05)$. Conclusion: Increase the awareness of family by nurses to provide safe home environment for hospitalized children by educating the family home accidents, it is advisable to consider the families of education in the socio-cultural level.

Key Words: Home accidents, security measures, nursing,0-6 year children,

\section{Giriş ve Amaç}

Çocukluk çağında kazalar, önlenebilir sağlık sorunlarının, ölüm ve engelli yaşam nedenlerinin başında yer almaktadır ${ }^{(1)}$. Çocuğun kaza/yaralanma riski yaş, cinsiyet, sağlık durumu, ekonomik durum, tek ebeveyn olmak, annenin eğitim düzeyi, annenin çalışma durumu, kalabalık aile, anne-babanın madde veya alkol kullanımı gibi durumlar ile yakından ilişkilidir ${ }^{(2,3)}$. Çocuğun hareketli olması, bilişsel ve davranışsal gelişimini tamamlamamış olması, çevreyi tanımak için ağzını ve ellerini kullanması, otonomisinin gelişmemiş olması ve bağımsız hareket edebilmesi de kaza riskini arttırmaktadır ${ }^{(4,5)}$.

Çocuklarda 0-4 yaş grubunda ve okul öncesi dönemde yaralanmalar s1klıkla evlerde olmaktadır ${ }^{(6)}$. Evlerde karşılaşılabilecek kaza türleri düşme, zehirlenme, yanma, elektrik çarpmaları, boğulma ve kesiklerdir ${ }^{(7)}$.

Dünya Sağlık Örgütü (DSÖ) ve Birleşmiş Milletler Çocuk Fonu'nun (UNICEF) 2008 raporuna göre, her gün 2000'den fazla çocuk kazalar sonucu ölmektedir ${ }^{(8)}$. Kazalarla ilgili en yoğun çalışmaların yapıldığı ülke olan Amerika Birleşik Devletleri'nde (ABD) yılda 25 milyon çocuk kazalar sonucu yaralanmaktadır. Unicef' in 2003 yılında 0-6 yaş grubu çocuklarla yaptığı bir çalışmasında, kaza geçiren çocukların \%71,3'ünün bu kazalara evde maruz kaldığı görülmüştür ${ }^{(8)}$. Avrupa' da bulunan altı ülkenin toplam verilerine göre, çocukluk yaş grubunda ev kaza sıklığg 44,9/1000 olarak bildirilmiştir ${ }^{(9)}$. ABD'de 5 yaş altı çocuklarda meydana gelen kazalar sonucunda oluşan yaralanmaların \%90'ının ve bu yaralanmalar sonucu oluşan ölümlerin \%50'sinin ev ortamında gerçekleştiği bildirilmektedir $^{(10)}$.

Türkiye'de ev kazalarına ilişkin geniş kapsamlı çalışmalar yoktur. Farklı illerde, farklı özelliklerdeki örneklem grupları ile yapılan araştırmalarda ev kazası sıklığının \%18-25 arası olduğu bildirilmektedir ${ }^{(11,12)}$. Kazalar ülkemizde 0-
4 yaş grubu çocuk ölümleri arasında beşinci s1rada, 5-14 yaş grubu çocuk ölümleri arasında ise birinci sırada yer almaktadır ${ }^{(13)}$.

Çocuklar kendilerini kazalardan koruyamadıkları için, kazalar açısından emniyetli ortamlarda yaşamaları, koruyucu önlemlerin alınması ve yaşam alanlarının güvenliğinin denetlenmesi erişkinlerin sorumluluğundadır. Bu sorumluluk da çoğu zaman çocukla daha çok birlikte olan anneye düşmektedir ${ }^{(14)}$. Ne yazık ki ülkemizde yapılan çalışmalarda, ailelerin kazalardan korunma bilgisi yetersiz, çocukların kaza geçirme riski yüksek bulunmuştur ${ }^{(15)}$.

Sağlik ekibinin bir üyesi olan hemşirenin görevleri arasında, sağlığın korunması ve geliştirilmesi de bulunmaktadır. Bu kapsamda, çocukluk çağında önemli bir mortalite ve morbidite nedeni olan ev kazalarının önlenmesi ve kazalar sonucunda oluşabilecek hasarın en aza indirgenmesinde hemşirelere büyük sorumluluklar düşmektedir $^{(16)}$. Çocukluk çağı yaralanmalarında hemşirenin rolleri arasında; çevredeki tehlikeleri tanımlamak, azaltmak ve ortadan kaldırmak, çocuklardaki davranış özelliklerini tanımlamak ve çocuk gelişimi konusunda ebeveynlere rehberlik etmek yer almaktadır ${ }^{(17)}$. Çocuk hemşireleri sağlik kontrolleri, ev ziyaretleri ya da çocuğun herhangi bir nedenle hastaneye yatması gibi durumlarda, annelere riskli durumlardan kaçınmayı sağlayacak gerekli bilgi ve danışmanlığı sağlamalıdir.

$\mathrm{Bu}$ araştırma "Hastanede yatan 0-6 yaş grubu çocukların annelerinin ev kazaları konusundaki bilgi ve uygulamalarını belirlemek" amacı ile planlanmıştır. Elde edilen verilerin, hemşirelerin annelere verecekleri eğitimlerin içeriğinin ve kapsamının belirlenmesinde, annelerin ev kazaları konusundaki farkındalık düzeylerinin arttırılmasında, ev kazaları konusunda uygun tutum ve davranışların geliştirilmesinde, çocuklarda ev kazalarının neden olduğu ölüm ve sakatlıkların azaltılmasında katkı sağlayacağı düşünülmektedir. 


\section{Gereç ve Yöntem}

\section{Araştırmanın Tipi ve Amacı}

Araştırma, hastanede yatan 0-6 yaş grubu çocukların annelerinin ev kazaları konusundaki bilgi ve uygulamalarını belirlemek amacı ile tanımlayıcı olarak planladi.

\section{Araştırmanın Yapıldığı Yer ve Zaman}

Araştırma bir Üniversitesi Sağllk Uygulama ve Araştırma Hastanesi çocuk kliniğinde Ekim 2012 - Mart 2013 tarihleri arasında gerçekleştirildi.

\section{Araştırmanın Evreni ve Örneklemi}

Araştırmanın evrenini Ekim-2012 ve Mart-2013 tarihleri arasında Sağlık Uygulama ve Araştırma Hastanesi çocuk kliniğinde $0-6$ yaş grubu çocuğu olan anneler, örneklemini ise aynı tarihler arasında, aynı hastane ve aynı klinikte 0-6 yaş grubu çocuğu yatan, araştırmaya katılmayı kabul eden 235 anne oluşturdu. Örneklem büyüklügüu, evreni bilinen grupta örneklem yöntemi kullanıla$\operatorname{rak}\left(\mathrm{n}=\mathrm{Nt^{2 }} \mathrm{pq} / \mathrm{d}^{2}(\mathrm{~N}-1)+\mathrm{t}^{2} \mathrm{pq}\right)$ belirlendi. Örneklem büyüklügü $\alpha=0,05$ anlamlllık düzeyinde, \pm $\% 5$ 'lik örnekleme hatası ile 235 olarak bulundu.

\section{Araştırma Soruları}

-Çocuklarda ev kazalarının oluşumunda etkili olan faktörler nelerdir?

-Çocuklarda ev kazaları görülme sıklığı nedir? -Ev kazaları görülme sıklığının, çocuk ve annelerin demografik özellikleri ile ilişkisi nedir?

-Annelerin "0-6 Yaş Çocuklarda Annenin Ev Kazalarına Yönelik Güvenlik Önlemlerini Tanımlama Ölçeğinden aldıkları puanları etkileyen değişkenler nelerdir?

\section{Araştırmada Kullanılan Araç-Gereç}

Araştırmada, veri toplama aracı olarak, anket formu ile "0-6 Yaş Çocuklarda Annenin Ev Kazalarına Yönelik Güvenlik Önlemlerini Tanımlama Ölçeği” kullanıldı.

Anket Formu: Verilerin toplanmasında, araştırmacılar tarafindan literatür incelenere ${ }^{(5,10,18-20)}$ hazırlanmış anket formu kullanıldı. Anket formu 3 bölümden oluştu. Sosyo-demografik özellikler soru formu annenin yaşı, eğitim durumu, çalışma durumu, çocuk sayısı, ailenin gelir durumu gibi bilgileri içeren 9 açık uçlu, 22 kapalı uçlu olmak üzere 31 sorudan; Ev kazaları bilgi düzeyi değerlendirme formu annelerin ev kazalarının önlenmesine yönelik bilgi düzeyleri ve farkındalıklarını ölçen 3 açık uçlu, 41 kapalı uçlu olmak üzere 44 sorudan; Ev kazalarında yapılacak girişimler konusunda bilgi düzeyi değerlendirme formu ise annelerin ev kazalarında yapılması gereken ilkyardım uygulamaları konusundaki bilgi düzeylerini belirlemek amacı ile geliştirilmiş 10 açık uçlu, 7 kapalı uçlu olmak üzere 17 sorudan oluşmaktayd.

0-6 Yaş Çocuklarda Annenin Ev Kazalarına Yönelik Güvenlik Önlemlerini Tanımlama Ölçeği: Çınar ve Görak (2003) ${ }^{(18)}$ tarafından geliştirilmiş " $0-6$ Yaş Çocuklarda Annenin Ev Kazalarına Yönelik Güvenlik Önlemlerini Tanımlama Ölçeği” ile annelerin ev ortamında sıkça karşılaşılan ev kazalarından (düşme, yanma, elektrik çarpması, kesikler, zehirlenme, boğulma) çocuğu korumak için aldıkları güvenlik önlemleri değerlendirildi. Ölçek 34 olumlu, 6 olumsuz ifade içeren toplam 40 maddeden oluşmaktadır. Beşli likert tipi olan ölçekte her bir madde 1'den 5'e kadar puanlanmış olup puanlar yanıtlara göre değişmektedir. Olumlu ifade içeren maddelerde her zaman cevabı 5 puan, çoğu zaman 4 puan, bazen 3 puan, nadiren 2 puan, hiçbir zaman 1 puan almakta iken, olumsuz ifade içeren $6,9,23,26,30$ ve 40'1ncı maddeler tersten puanlanmaktadır. Ö1çekten alınabilecek puan minimum 40; maksimum 200 dür.

\section{Verilerin Toplanması}

$\mathrm{Bu}$ araştırmanın verileri, gerekli izinler alındıktan sonra Sağlık Uygulama ve Araştırma Hastanesi çocuk kliniğinde Ekim 2012 - Mart 2013 tarihleri arasında yatan, 0-6 yaş aralığındaki çocukların araştırmaya gönüllü olarak katılmayı kabul eden anneleri ile yapılan görüşmelerden elde edildi. Uygulamaya başlamadan önce annelere araştırmanın amacı açıklanarak araştırma ile ilgili bilgi verildi ve çalışmaya katılmaları konusunda yazılı onamları alındı. Veriler, anket formunun, araştırmacı tarafindan annelerle yüz yüze görüşme yöntemi ile doldurulması sonucu elde edildi.

Araştırma verileri toplanmadan önce, verilerin toplanacağı hastaneden 10 anne ile yüz yüze görüşme yöntemi ile pilot uygulama yapıldı. Pilot uygulamada anneler tarafindan soruların anlaş1lırlığ 1 incelenerek elde edilen veriler doğrultusunda soru formlar1 yeniden düzenlendi. Pilot uygulama verileri araştırma verileri arasında yer almadi.

\section{Verilerin Değerlendirilmesi}

Çalışmada elde edilen bulgular değerlendirilirken, istatistiksel analizler için SPSS (Statistical Packagefor Social Sciences) for Windows 20.0 programı kullanıldı. Verilerin normal dağılıma 
uygunluğu Shapiro-Wilk testi ile incelendi. Değişkenlerin normal dağılım göstermemesinden dolay1 Kruskal Wallis testi ve Mann-Whitney U testi ile karşılaştırmalar yapıldı. Değişkenler arasındaki ilişkiler Spearman sıra korelasyon katsayısı ile incelendi. Verilerin normal dağılım göstermemesinden dolayı betimleyici değerler median (min-max) olarak, kategorik veriler ise frekans ve yüzde olarak verildi. Kategorik verilerin gruplar arası karşılaştırılmasında ki-kare ve Fisher'in kesin ki-kare testi kullanıldı. İstatistiksel anlamlılık düzeyi olarak $\alpha=0,05$ alındı. Ölçek güvenilirliği iç tutarlılık katsayısı olan Cronbach's Alpha katsayısı ile değerlendirildi ve ölçeğin güvenilir olduğu sonucuna varıldı $(0,78)$. Araştırmaya başlamadan önce Uludağ Üniversitesi Tıp Fakültesi Klinik Araştırmalar Etik Kurulundan araştırma için onay alındı.

\section{Bulgular}

Tablo 1. Ailenin Sosyo-Demografik Özelliklerinin Dağılımı

\begin{tabular}{|c|c|c|}
\hline Demografik Özellikler & $\mathbf{O r t} \pm \mathbf{S s}$ & $\begin{array}{l}\text { Min- } \\
\text { max }\end{array}$ \\
\hline Anne yaşı (yıl) & $30 \pm 5,73$ & $19-53$ \\
\hline Baba yaşı (yıl) & $33 \pm 6$ & $23-58$ \\
\hline Çocuğun yaşı (ay) & $24 \pm 21,99$ & $1-72$ \\
\hline Çocuk sayısı & $2 \pm 0,93$ & $1-8$ \\
\hline Demografik Özellikler & n & $\%$ \\
\hline \multicolumn{3}{|l|}{ Çocuğun cinsiyeti } \\
\hline Erkek & 129 & 54,9 \\
\hline $\mathrm{K} 1 \mathrm{z}$ & 106 & 45,1 \\
\hline \multicolumn{3}{|l|}{$\begin{array}{l}\text { Annenin eğitim du- } \\
\text { rumu }\end{array}$} \\
\hline İlkokul ve altı & 116 & 49,4 \\
\hline Ortaokul mezunu & 42 & 17,9 \\
\hline Lise mezunu & 44 & 18,7 \\
\hline Üniversite mezunu & 33 & 14 \\
\hline \multicolumn{3}{|l|}{$\begin{array}{l}\text { Babanın eğitim } \\
\text { durumu }\end{array}$} \\
\hline İlkokul ve altı & 84 & 35,8 \\
\hline Ortaokul mezunu & 35 & 14,9 \\
\hline Lise mezunu & 78 & 33,2 \\
\hline Üniversite mezunu & 38 & 16,1 \\
\hline \multicolumn{3}{|l|}{$\begin{array}{l}\text { Annenin çalışma } \\
\text { durumu }\end{array}$} \\
\hline Çalışıor & 37 & 15,7 \\
\hline Çalışmıyor & 198 & 84,3 \\
\hline \multicolumn{3}{|l|}{ Aile tipi } \\
\hline Geniş aile & 51 & 21,7 \\
\hline Cekirdek aile & 183 & 77,9 \\
\hline Parçalanmış aile & 1 & 0,4 \\
\hline
\end{tabular}

\begin{tabular}{|c|c|c|}
\hline $\begin{array}{l}\text { Tablo 1. Ailenin Sosyo-D } \\
\text { lerinin Dağılımı (Tablo }\end{array}$ & $\begin{array}{l}\text { logra } \\
\text { deva }\end{array}$ & ellik \\
\hline Ailedeki çocuk sayısı & & \\
\hline 1 çocuk & 75 & 31,9 \\
\hline 2 çocuk & 114 & 48,5 \\
\hline 3 ve üzeri çocuk & 46 & 19,6 \\
\hline Ev tipi & & \\
\hline Apartman dairesi & 126 & 53,6 \\
\hline Müstakil ev & 101 & 43 \\
\hline Gecekondu & 8 & 3,4 \\
\hline Çocuk odası varlığı & & \\
\hline Var & 144 & 61,3 \\
\hline Yok & 91 & 38,7 \\
\hline $\begin{array}{l}\text { Çocuğun uyuma } \\
\text { ortamı }\end{array}$ & & \\
\hline $\begin{array}{l}\text { Ebeveyn yatak odas1, } \\
\text { kendi yatağında }\end{array}$ & 158 & 67,2 \\
\hline $\begin{array}{l}\text { Kardeşleriyle aynı oda, } \\
\text { ayrı yatakta }\end{array}$ & 49 & 20,9 \\
\hline $\begin{array}{l}\text { Tek başına ayrı odada, } \\
\text { ayr1 yatakta }\end{array}$ & 18 & 7,7 \\
\hline $\begin{array}{l}\text { Ebeveynleri ile aynı } \\
\text { yatakta }\end{array}$ & 9 & 3,8 \\
\hline $\begin{array}{l}\text { Kardeşleriyle aynı oda, } \\
\text { aynı yatakta }\end{array}$ & 1 & 0,4 \\
\hline
\end{tabular}

Tablo 1 incelendiğinde; Annelerin yaş

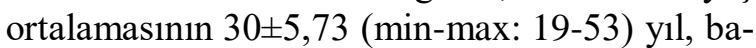
baların yaş ortalamasının $33 \pm 6,00$ (min-max: 23 58) y1l, çocukların yaş ortalamasının $24 \pm 21,99$ (1-72) ay, ailedeki ortalama çocuk sayısının $2 \pm 0,93$ (min-max: 1-8) yıl, olduğu, çocukların $\% 45,1$ 'inin kız olduğu, annelerin \%49,4'ünün $(\mathrm{n}=116)$, babaların ise \% 35,8' inin $(\mathrm{n}=84)$ ilkokul ve alt1 eğitime sahip olduğu, Annelerin \%84.3'ünün $\quad(\mathrm{n}=198) \quad$ çalışmadığı, ailelerin $\% 77,9$ 'unun ( $\mathrm{n}=183$ ) çekirdek aile yapısına sahip olduğu, \% 48.5'inin (n=114) 2 çocuğa sahip olduğu, \% 53.6'sının (n=126) apartmanda yaşadığı, $\%$ 61.3'ünün $(\mathrm{n}=144)$ evinde çocuk odası olduğu, çocukların sadece \% 7.7'sinin $(n=18)$ tek başına ayrı odada ayrı yatakta yattığı belirlendi.

Araştırmaya katılan çocukların \%30,2'sinin $(n=71)$ en az bir kez ev kazasina maruz kaldığı, geçirilen kaza türleri arasında düşmelerin \% 55 ile $(n=44)$ ilk sırada yer aldığı, kazaların meydana geldiği yer açısından bakıldığında kazaların en sik (\%62.5) evin salonu/ oturma odasinda meydana geldiği, annelerin \%40'ının $(\mathrm{n}=32)$ annenin ihmali nedeniyle, $\% 52,5$ 'inin $(n=42)$ çocuğun dikkatsizliği nedeniyle kazaların meydana geldiğini düşündüğü, kazaların $\% 55$ 'inde $(n=44)$ çocuğun yanında annesinin olduğu zamanlarda meydana geldiği, kaza geçiren çocukların 
\%60'nin daha önce ev kazası nedeniyle sağlık kuruluşuna götürüldüğüu, $\% 21,2$ 'sinin $(\mathrm{n}=17)$ daha önceden kaza nedeni ile hastanede yattığ 1 , çocuğu kaza geçiren annelerin sadece \%36,3'ünün $(n=29)$ kaza sonrası evde önlemler aldığını ifade ettiği belirlendi. Annelerin sadece \%6,4'ü $(n=15)$ daha önce ev kazalarına yönelik eğitim aldığını bildirdi.

Tablo 2. Çocuklarda Ev Kazası Geçirme Durumuna İlişkin Özelliklerin Dağılımı

\begin{tabular}{lcc}
\hline $\begin{array}{l}\text { Tanımlayıcı Özellikler } \\
\text { Ev kazasına maruz kalma } \\
\text { durumu }\end{array}$ & $\mathbf{n}$ & $\mathbf{c}$ \\
Evet & & \\
Hayıı & 71 & 30,2 \\
Geçirilen Kazanın türü & 164 & 69,8 \\
Düşmeler & & \\
Yanıklar & 44 & 55 \\
Kesikler & 24 & 30 \\
Diğer (Zehirlenme, boğulma) & 8 & 10 \\
Ev kazasının meydana geldiği & 4 & 5 \\
yer & & \\
Salon & 50 & 62.5 \\
Mutfak & 11 & 13.7 \\
Yatak odası & 6 & 7.5 \\
Banyo & 6 & 7.5 \\
Diğer (merdiven, çocuk odası & & \\
& 7 & 8.8
\end{tabular}

Tablo 2. Çocuklarda Ev Kazası Geçirme Durumuna İlişkin Özelliklerin Dağılımı (Tablo 2'nin devamı)

\section{Anneye göre ev kazasının sebebi}

Çocuğun dikkatsizliği $\quad 42 \quad 52,5$

Annenin ihmali $\quad 32 \quad 40$

Çevre faktörü $\quad 6 \quad 7,5$

Ev kazasında yanındaki kişi

Anne $\quad 44 \quad 55$

Diğer aile üyeleri (baba, dede vs) $\quad 36 \quad 45$

Ev kazası nedeniyle sağlık ku-

ruluşuna götürme*

Evet $\quad 48 \quad 60$

Hayır $\quad 32 \quad 40$

Ev kazası nedeni ile hastaneye

yatma durumu

$\begin{array}{lll}\text { Evet } & 17 & 21,2\end{array}$

$\begin{array}{lll}\text { Hayir } & 63 & 78,8\end{array}$

Ev kazası sonrası

önlem alma durumu

$\begin{array}{lrr}\text { Evet } & 29 & 36,3\end{array}$

$\begin{array}{lll}\text { Hayır } & 51 & 63,7\end{array}$

Ev kazaları konusunda eğitim

alma durumu

$\begin{array}{lll}\text { Evet } & 15 & 6,4\end{array}$

\begin{tabular}{lrr} 
Hayır & 220 & 93,6 \\
\hline * Bazı çocuklar birden fazla kazaya maruz kaldıkları
\end{tabular} için kaza sayısı, toplam n sayısından fazladır.

Tablo 3. Çocukların Ev Kazalarına Maruz Kalma Durumları ile Ev Kazalarını Etkileyebilecek Değişkenlerin Karşılaştırılması

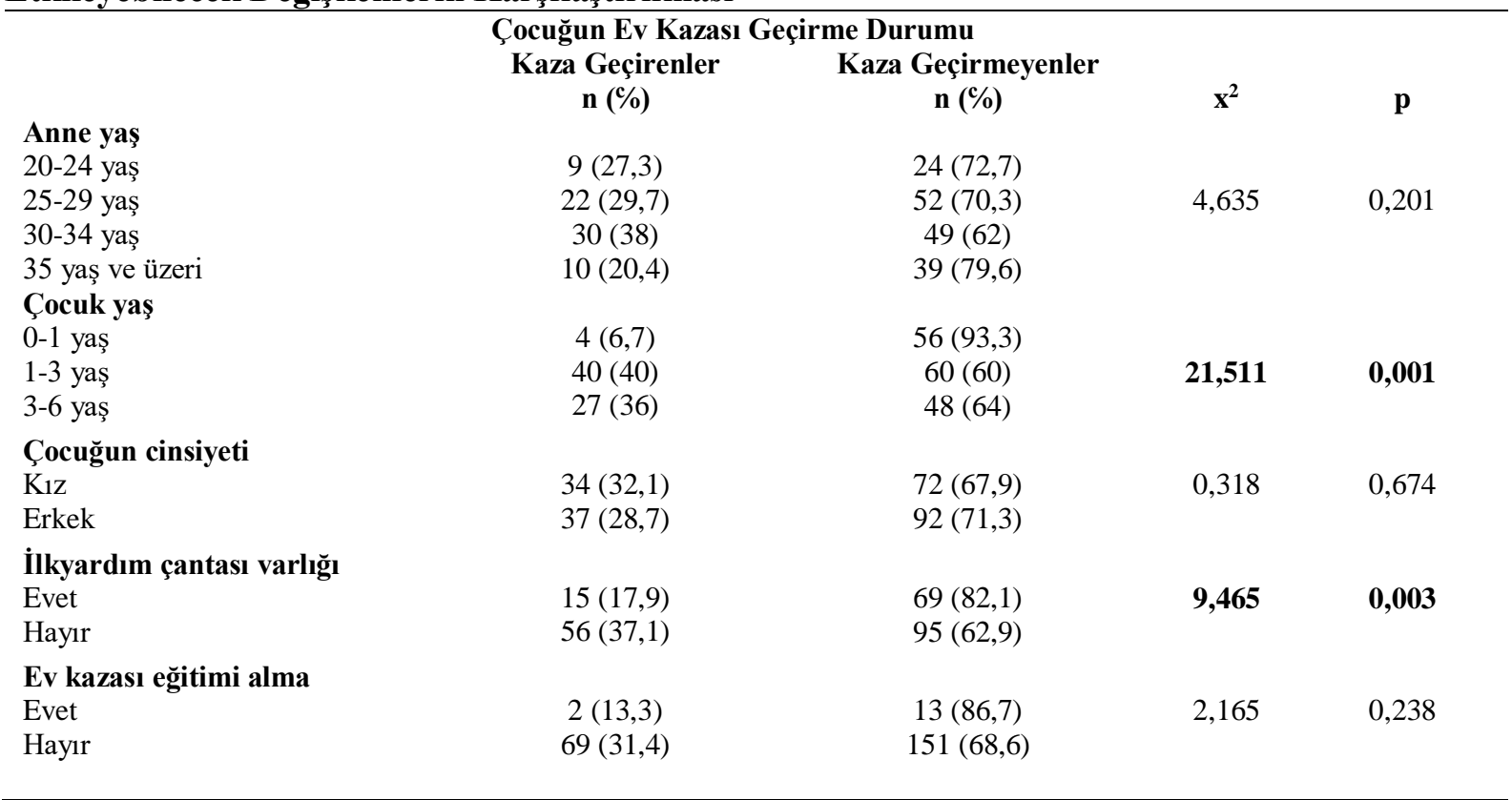

*Ki-kare testi

Çocukların ev kazalarına maruz kalma durumları ile anne yaş grupları, çocuğun cinsiyeti ve anne- lerin ev kazaları konusunda eğitim alma durumları arasında istatistiksel olarak anlamlı bir ilişkiye rastlanmadı $(\mathrm{p}>0,05)$. Çocuk yaş grupları ile 
çocukların ev kazalarına maruz kalma durumları karşılaştırıldığında, aralarında istatistiksel olarak anlamlı bir fark olduğu belirlendi $(\mathrm{p}<0,001)$. Ev kazalarının 1-3 yaş arası görülme sıklı̆̆ı anlamlı şekilde yüksek, 0-1 yaş arası görülme sıklığı ise anlamlı ölçüde düşük bulundu.

Evde ilkyardım çantası varlığı ile çocukların ev kazalarına maruz kalma durumları arasında istatistiksel olarak anlamlı bir ilişki olduğu

Tablo 4. Annelerin Ölçek Puan Ortalamaları ile Ailenin Sosyo-Demografik Özelliklerinin Karşılaştırılması

\begin{tabular}{|c|c|c|c|c|}
\hline Demografik Özellikler & $\mathbf{N}$ & Ort \pm Ss & $\mathbf{r}$ & $\mathbf{p}$ \\
\hline Annenin yaşı & 235 & $30 \pm 5,73$ & 0,067 & 0,306 \\
\hline Babanın yaşı & 235 & $33 \pm 6,008$ & 0,045 & 0,489 \\
\hline Çocuğun yaşı (ay) & 235 & $24 \pm 21,99$ & $-0,098$ & 0,134 \\
\hline Çocuk sayısı & 235 & $2 \pm 0,93$ & $-0,040$ & 0,537 \\
\hline Demografik Özellikler & $\mathbf{n}$ & Ort \pm Ss & $\mathbf{p}$ & \\
\hline $\begin{array}{l}\text { Aylık gelir durumu } \\
\text { 500-1000TL aras1 } \\
\text { 1000-2500TL aras1 } \\
\text { 2500TL ve üzeri } \\
\text { Düzenli geliri yok }\end{array}$ & $\begin{array}{l}80 \\
92 \\
34 \\
29\end{array}$ & $\begin{array}{l}159,81 \pm 15,11 \\
165,65 \pm 13,67 \\
167,65 \pm 10,88 \\
167,28 \pm 10,14\end{array}$ & 0,005 & \\
\hline $\begin{array}{l}\text { Annenin eğitim durumu } \\
\text { İlkokul mezunu ve altı } \downarrow \\
\text { Ortaokul mezunu ve üzeri } \uparrow\end{array}$ & $\begin{array}{l}116 \\
119\end{array}$ & $\begin{array}{l}163 \pm 14,08 \\
170 \pm 12,57\end{array}$ & 0,001 & \\
\hline $\begin{array}{l}\text { Babanın eğitim durumu } \\
\text { İlkokul mezunu ve altı } \downarrow \\
\text { Ortaokul mezunu ve üzeri } \uparrow\end{array}$ & $\begin{array}{c}84 \\
151\end{array}$ & $\begin{array}{c}164,50 \pm 15,72 \\
168 \pm 12,09\end{array}$ & $\mathbf{0 , 0 1 0}$ & \\
\hline $\begin{array}{l}\text { Annenin çalışma durumu } \\
\text { Çalışıyor } \\
\text { Çalışmıyor }\end{array}$ & $\begin{array}{c}37 \\
198\end{array}$ & $\begin{array}{l}169 \pm 13,37 \\
166 \pm 13,82\end{array}$ & 0,240 & \\
\hline $\begin{array}{l}\text { Aile tipi } \\
\text { Geniş aile } \\
\text { Çekirdek aile } \\
\text { Parçalanmış aile }\end{array}$ & $\begin{array}{c}51 \\
183 \\
1\end{array}$ & $\begin{array}{c}164 \pm 17,15 \\
167 \pm 12,63 \\
153\end{array}$ & 0,322 & \\
\hline $\begin{array}{l}\text { Çocuk odası varlı̆̆ı } \\
\text { Var } \\
\text { Yok }\end{array}$ & $\begin{array}{c}144 \\
91\end{array}$ & $\begin{array}{l}169 \pm 12,07 \\
162 \pm 15,25\end{array}$ & 0,001 & \\
\hline
\end{tabular}

Anne ve babaların eğitim durumu, ailenin aylık gelir durumu, çocuk odası varlığı ile ölçek puan ortalaması arasında aynı yönde anlamlı bir ilişki olduğu, aylık gelir arttıkça ölçek puanlarının arttığı belirlendi $(\mathrm{p}<0.05)$. belirlendi ( $\mathrm{p}=0,003)$. Evinde ilk yardım çantası bulunduran ailelerin çocuklarının, istatistiksel düzeyde anlamlı ölçüde daha az ev kazasına (\%17,9) maruz kaldığ 1 saptandı. 


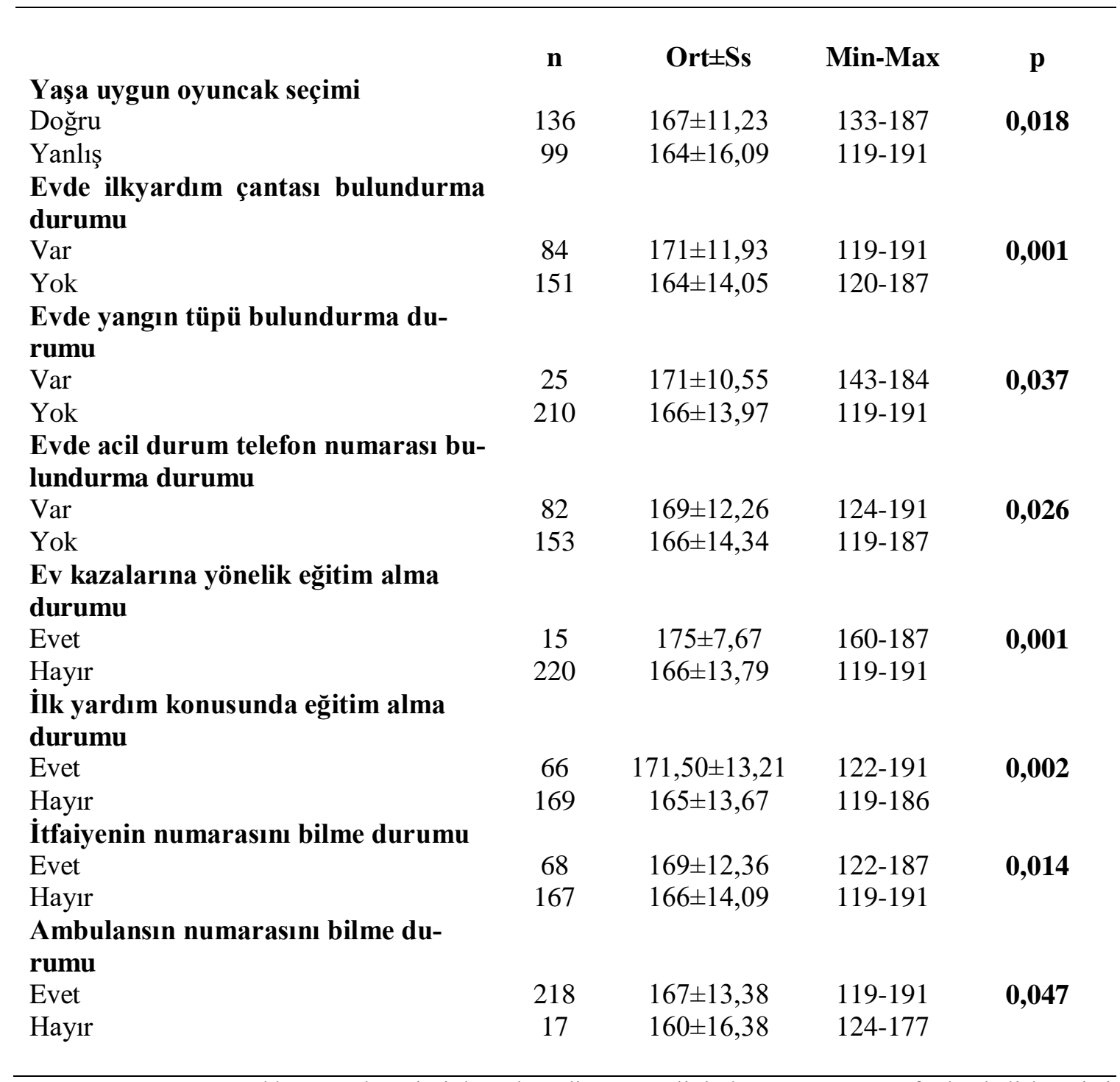

*Mann-WhitneyUtesti, **Oyuncak seçimi doğruluğu literatür eşliğinde araştırmacı tarafından belirlenmiştir

Tablo 5 incelendiğinde; annelerin, yaşa uygun oyuncak seçimi, evde ilk yardım çantası, yangın tüpü, acil durum telefon numarası bulundurma, ev kazalarına yönelik eğitim alma, ilk yardım konusunda eğitim alma, itfaiyenin ve ambulansin telefon numarasını bilme ile annelerin ölçek puan ortalamaları arasında istatistiksel düzeyde anlamlı fark olduğu görüldü $(\mathrm{p}<0.05)$.

\section{Tartışma}

Ev kazaları sıklı̆̆ değişmekle beraber çocukluk çağı kazalarının $\% 25$ 'ini oluşturduğu bilinmektedir ${ }^{(21)}$. Araştırma grubunun sosyodemografik verileri Tablo 1'de görülmektedir. Çocuklarda ev kazası görülme s1klığ1 \%30,2 olarak belirlenmiștir (Tablo 2). Bazı çalışmalardaki sonuçlar bizim çalışmamızla paralellik gösterirken ${ }^{(20-23)}$ sosyoekonomik düzeyi düşük olan ailelerle yapılmış bazı çalışmalarda kaza sıklığ 1 \% 49,6; Balibey ve arkadaşlar1nın (2011) (24)'nın Ankara'da kentsel, yarı kentsel ve kırsal yaşam alanlarında yaşayan, 1-5 yaş arası çocuğu olan annelerle yapmış olduğu çalışmasinda kaza siklığ $\% 65,6$; Dal Santo ve arkadaşlarının (2004) ${ }^{(25)}$ Kuzey Carolina'da yaşayan 5 yaş altı çocuğa sahip annelerle yaptığı çalışmasında ise kaza insidansı $\% 65$ bulunmuştur. Bu çalışmadan farklı olarak Manisa' da herhangi bir nedenle sağlık ocağına başvuran, 0-6 yaş arası çocuklarda kaza sıklığ $\% 15,5$ olarak belirnemiş$\operatorname{tir}^{(12)}$. Bu sonuçların araştırmaların farklı bölgelerde, farklı yaş gruplarında ve farklı yıllarda yapılan lokal çalışmalar olmasından kaynaklandığ düşünülmektedir.

Araştırmada en sık karşılaşılan kaza türlerinin düşmeler $(\% 55)$ ve yanmalar $(\% 30)$ olduğu belirlendi (Tablo 2). Benzer olarak çoğu ça- 
lışmada da düşmeler en sık karşılaşılan ev kazaları arasında belirtilmiştir ${ }^{(2,12,18,20-34)}$. Ev kazaları arasında ikinci sırada yanmaların bulunduğunu gösteren çalışmalarda azımsanmayacak kadar çoktur $^{(6,12,18,20-23,29,35)}$. Çocuklarda kaza bilincinin henüz gelişmemiş olması, vücut dengelerini sağlamadaki yetersizlikleri, hareketli ve dikkatsiz oluşları, bulma ve öğrenme konusundaki merakları çocuklarda düşmelerin yaygın olarak görülmesine zemin hazırlamaktadır. Konuyla ilgili verilecek eğitimlerde anne babaların ilgisi bu yöne çekilmeli, yaygın olarak görülen ev kazalarının önlenmesinde gerekli tedbirlerin alınmasının gerekliliği vurgulanmalıdır.

Ev kazası geçiren çocukların, kaza esnasında yanlarında çoğunlukla (\%55) annelerinin bulunduğu görülmektedir (Tablo 2). Literatürde de çoğu çocuğun ev kazası esnasında annesi ile birlikte olduğu belirtilmiştir ${ }^{(26,37,38)}$. Bu sonuç, sanılanın aksine kazaların çocuk yalnız iken meydana gelmediğini göstermesi bakımından önemlidir. Annenin çocuğun yanındayken dikkatli gözlemini sürdürmesi konusunda bilgilendirilmesi önerilebilir.

$\mathrm{Bu}$ çalışmada annelerin $\% 52,5$ 'i çocuğun dikkatsizliği sonucu, \%40'1 kendi ihmalleri nedeniyle, kaza oluştuğunu ifade etti (Tablo 2). Yapılan çalışmalar, ev kazalarının bazen çevredeki tehlikeli durumlardan, bazen de hatalı davranışlardan fakat genellikle her ikisinin birleşmesinden ileri geldiğini göstermektedir ${ }^{(39)}$. Annelerin çoğunluğunun kaza oluşumundan çocukları sorumlu tutmas1, ev kazaları konusundaki sorumluluklarını yatsıma eğiliminde olduklarını düşündürdü.

Araştırmada kaza geçiren çocuklardan sadece \%60'ının ailesi tarafindan bir sağlık kuruluşuna götürüldüğü belirlendi (Tablo 2). Farklı çalışmalarda ailelerin çocuklarını kaza sonrası sağlık kuruluşuna götürme sıklığının \% 24-60,4 arasında değiştiği belirlenmiştir (20-23,34,40,). Bazı annelerin evde müdahaleyi tercih etmelerinin ya da herhangi bir müdahalede bulunmamalarının bu sonucu doğurduğu düşünüldü.

Çalışmada çocukların ev kazalarına en çok oturma odas1/salonda (\% 62,5), ikinci sırada mutfakta $(\% 13,7)$, maruz kaldığ saptandı (Tablo 2). Literatürde en fazla kaza yaşanan alan olarak oturma odas1/salon bildirilse $\mathrm{de}^{9,26,29,36,41}$, nadir olarak bahçe ${ }^{(30)}$, mutfak ${ }^{(42-44)}$, yatak odasi ${ }^{(45)}$ ve banyoda $\mathrm{da}^{(46)}$ kaza sıklığ 1 bildirilmiştir. En sık kaza yaşanan alan olarak ikinci sırada mutfağı belirten çalışmalarda ${ }^{(26,36)}$ bu çalışma ile benzerlik göstermektedir. Çocuklarda ev kazalarının en sık oturma odas1/salonda gerçekleşmesinin, ailelerin vakitlerinin çoğunu oturma odas1/salonda geçirmesinden kaynaklandığı sonucuna varılmıştır. $\mathrm{Bu}$ sonuç ailelerin, en çok vakit geçirdiği ortam olan oturma odasi/ salonun kaza riski açısından ilk sırada yer aldığı konusunda farkındalık düzeylerinin arttırılması ve ev kazalarını önlemeye yönelik salonda gerekli tedbirleri alması konusunda bilinçlendirilmesi gerektiğini düşündürdü.

Ev ortamlarının çocuk güvenliğini sağlayacak şekilde düzenlenmemesi ev kazası riskini arttıran nedenlerden biridir ${ }^{(47)}$. Bu çalışmada kaza sonrası önlem alınma sıklığ $\% 36,3$ olarak belirlendi (Tablo 2). Literürde annelerin kaza sonras1 önlem alma sıklığının \% 27.5 ile \% 76 arasında değişen farklı önlem alma sıklığı belirleyen çalışmalar mevcuttur ${ }^{(20-23,40)}$. Araştırma kapsamındaki annelerin kaza deneyimlerinin sinırlı olması sebebi ile önlem alma eğilimlerinin az olduğu düşünüldü.

Çalışmada ev kazalarının oluşumunda anne yaşının etkisinin olmadığı görüldü $(p>0,05)$ (Tablo 3). 0-6 yaş grubu çocuğa sahip annelerle yapılan başka bir çalışmada da benzer sonuçlara ulaşılmışıır ${ }^{(34)}$. Bunun yanı sıra kaza sıklığı ile anne yaşı arasında ilişki olduğunu belirleyen araştırmalar da vardır. Bazı çalışmalarda anne baba yaşı arttıkça kaza sıklığının azaldığı bildirilmektedir ${ }^{(26,23,34)}$.

Araştırma sonuçları, literatürle uyumlu şekilde ${ }^{(8)}$ çocuk yaşının kaza oluşumuna etkisinin olduğu, ev kazalarının en sık 1-3 yaş arası çocuklarda (\%56,3) görüldüğünü göstermektedir $(\mathrm{p}<0,001)$ (Tablo 3). Bu sonuçlar, çocuklarda ev kazalarının gelişme sıklığının çocukların gelişimsel özellikleri ile ilişkili olduğunu düşündürdü. Ebeveynlere verilecek eğitimlerde çocukların gelişimsel özelliklerinin ve yaşının ev kazaları ile ilişskisinin vurgulanması ve yaş dönemine özgü olarak ele alınması gerektiği sonucuna varıldı.

Araştırmada kaza geçirme sıklığı ile cinsiyet arasında anlamlı bir ilişkiye rastlanmadı (p>0,05)(Tablo 3). Ankara'da 0-48 ay arası çocuğa sahip annelerle yapılan bir çalışmada ${ }^{(30)}$ benzer şekilde ev kazası oluşumu ile cinsiyet arasında herhangi bir ilişki olmadığı sonucuna varılmıştır. Literatürde erkek çocuklarının kız çocuklarından daha fazla kazaya maruz kaldığını bildiren çok sayıda çalışmaya rastlanmış$\operatorname{tır}^{2,3,12,26,31,34,41,45,48,49}$. Çoğu çalışmada erkek çocuklarının daha fazla ev kazası geçirmesinde hareketli, merakl1, disiplinsiz, dikkatsiz oluşları ile sert oyunları sevmelerinin etkisi olduğu belirtilmiştir. Balibey ve arkadaşalarının $(2011)^{(24)}$ çalışmasında, erkek çocuklarının kaza geçirme hızı 
kırsal yaşam alanında daha yüksek ve anlamlı bulunurken, kentsel ve yarı kentsel alanda cinsiyet farkı anlamlı bulunmamıştır. Kentsel alanlarda apartman dairesinde oturan çocukların vakitlerinin çoğunu evde geçirmesinin, kaza oluşumunda cinsiyet farkını ortadan kaldırdığı düşünülebilir.

Çalışmada evinde ilk yardım çantası bulundurma durumu ile kaza görülme sıklığı arasinda istatistiksel olarak anlamlı bir ilişki olduğu belirlendi $(\mathrm{p}=0,003)$ (Tablo 3). İlkyardım çantası bulundurmak kazalara karşı bir tedbir olduğundan, tedbir alma eğiliminde olanların kaza konusundaki farkındalık düzeylerinin daha yüksek olduğu ifade edilebilir.

Anne yaşı ile ölçek puan ortalaması arasında, istatistiksel olarak anlamlı bir ilişkiye rastlanmadı ( $>>0,05)$ (Tablo 4). Dericioğulları ve arkadaşlarının(2007) ${ }^{(50)}$ çalışmasında, Öztürk ve arkadaşlarının (2010) ${ }^{(51)}$ çalışmasında annelerin yaşları ile ölçek puan ortalamaları arasında anlamlı bir ilişki bulunmadığı belirlenmiştir. Araştırma sonuçları bu çalışmalarla uyumludur. Koştunun $(2005)^{(52)}$ çalışmasında, annenin yaşı arttıkça ölçek puan ortalamasının düştüğü, Turan ve Ceylanın (2007) ${ }^{(36)}$ ile Özmen ve arkadaşlarının $(2007)^{(12)}$ çalışmalarında ise yaşı büyük annelerin ölçek puanının daha yüksek olduğu bildirilmektedir.

$\mathrm{Bu}$ çalışmada literatürle uyumlu şekilde $^{(32)}$ ailedeki çocuk sayısı ile ölçek puan ortalaması arasında istatistiksel olarak anlamlı bir iliş̧ki olmadığı belirlendi ( $\mathrm{p}=0,53)$ (Tablo 4).

Ailenin gelir düzeyi ile ölçek puan ortalaması arasında anlamlı bir ilişki olduğu, ailelerin gelir düzeyleri arttıkça annelerin ölçek puan ortalamalarının da arttı̆ğ belirlendi $(\mathrm{p}=0,005)$ (Tablo 4). Erkal'ın (2010) ${ }^{(37)}$ çalışma sonuçları ile Turan ve Ceylan'ın (2007) ${ }^{(36)}$ çalışma sonuçları araştırma sonuçlarımız ile benzer şekilde ailenin gelir düzeyi arttıkça ölçek puanlarının arttığı belirlenmiştir. Farklı olarak Aktaş'ın (2010) ${ }^{(32)}$ çalışmasındaki ailelerin gelir düzeyleri ile annelerin ölçek puan ortalamalarının karşılaştırılması istatistiksel olarak anlamlı bulunmamıştır. Gelir düzeyi az olan ailelerde eğitim seviyesinin de daha düşük olmasının ayrıca gecekondu yaşamının yaygınlığının, ev kazaları konusunda gerekli bilgilerin edinilmesine ve ev içinde gerekli düzenlemelerin yapılabilmesine olanak vermediği düşünüldü.

$\mathrm{Bu}$ çalışmada anne ve babanın eğitim düzeyi yükseldikçe, ölçekten aldıkları toplam puanın da arttığı belirlendi $(\mathrm{p}<0,05)$ (Tablo 4). Birçok araştırmada, bu çalışmaya paralel olarak annenin eğitim durumu ile ölçek puan ortalaması arasında aynı yönde anlamlı bir ilişki olduğu bildirilmektedir $^{36,37,51,52}$.

Araştırmada aile tipi ile annelerin ölçek puan ortalamaları arasında, istatistiksel düzeyde anlamlı bir ilişkiye rastlanmadı $(\mathrm{p}=0,322)$ (Tablo 4). Aktaş'ın $(2010)^{(32)}$ çalışmasında da benzer sonuçlara ulaşılmıştır. Koştu'nun (2005) ${ }^{(52)}$ çalışmasında, aile tipi ile ölçek puan ortalaması arasında istatistiksel bir fark olduğu saptanmıştır. Turan ve Ceylan'ın (2007) ${ }^{(36)}$ çalışmasında çekirdek ailede yaşayan annelerin; Erkal'ın (2010) ${ }^{(37)}$ çalışmasında ise geniş ailelerdeki annelerin ölçek puan ortalamaları daha yüksek bulunmuştur.

Annelerin çalışma durumları ile ölçek puanı arasında anlamlı bir ilişki saptanmadı( $\mathrm{p}=0,240)($ Tablo 4). Bu sonuçlar literatürle uyumlu bulundu ${ }^{(50)}$.

Çalışmada evinde çocuk odası bulunan annelerin ölçek puan ortalamalarının, evinde çocuk odası bulunmayan annelerin ölçek puan ortalamalarından daha yüksek olduğu saptandı $(p<0,001)$ (Tablo 4). Evinde çocuk odası bulunan ailelerin sosyoekonomik durumlarının daha iyi olduğu düşünülürse, bu özelliklere sahip ailelerin kazalara karşı önlem alma eğilimlerinin de fazla olduğu söylenebilir.

$\mathrm{Bu}$ araştırmada çocuğun yaşı ile annelerin ölçek puan ortalamaları arasında istatistiksel düzeyde anlamlı bir ilişkiye rastlanmadı $(\mathrm{p}=0,134)$ (Tablo 4). Yapılan bir çalışmaya göre çocuğu 17 aydan büyük olan annelerin ölçekten daha yüksek puan aldığı ve bu sonucun istatistiksel olarak anlamlı olduğu saptanmıştır ${ }^{(12)}$. Yıldız Çiçekler ve arkadaşlarının (2012) ${ }^{(53)}$ yaptığı çalışmada, farklı aylar arasında çocuğu bulunan annelerin, ev kazalarına yönelik güvenlik önlemleri ölçeğinden aldıkları puanlar arasında anlamlı bir fark olduğu belirlenmiştir. Özmen ve arkadaşlarının çalışma sonuçları ile Yıldız Çiçekler ve arkadaşlarının çalışma sonuçları, bu çalışma sonuçları ile farklılık göstermiştir. Küçük çocuklarda yabancı cisim aspirasyonu ve yatakta dönmeye bağlı düşmeler daha fazla yaşanırken, daha büyük çocuklarda zehirlenmeler, yanmalar ve kesikler daha fazla görülmektedir. Bu nedenle annelerin tüm önlemler yerine sadece çocuğun yaşına uygun olan kazalara ait önlemleri alması, ölçek puan farklarını azaltıcı etki göstermiş olabilir.

Araştırmada çocuğun cinsiyeti ile annenin ölçek puan ortalaması arasında, istatistiksel olarak anlamlı bir ilişkiye rastlanmad $(\mathrm{p}=0,935)$ (Tablo 4). Benzer şekilde Yıldız Çiçekler ve arkadaşlarının (2012) $)^{53}$ yaptığı çalışmada da, annelerin ev kazalarına yönelik güvenlik önlemlerini 
alma durumu ile çocuğun cinsiyeti arasında anlamlı bir farklılığın olmadığ 1 belirlenmiş$\operatorname{tir}(p>0,05)$. Bu sonuçlar annelerin önlem almasında cinsiyetin belirleyici olmadığını düşündürmektedir.

Oyuncaklar çocuğun yaşına ve gelişim düzeyine uygun seçilmediği, sağlıklı malzemeden yapılmadığ 1 ve ortalıkta birakıldığ 1 durumlarda ciddi kazalara neden olabilmektedir. Bu çalişmada yaşa uygun oyuncak seçimi doğruluğu ile annelerin ölçek puan ortalamaları arasında istatistiksel düzeyde anlamlı bir ilişki olduğu belirlendi ( $\mathrm{p}=0,018)$ (Tablo 5). Kazalardan koruma bilinci yüksek olan annelerin, oyuncak seçimi konusunda da duyarlı olduğu söylenebilir.

Çalışmada ev kazaları konusunda eğitim alan annelerin ölçek puan ortalamalarının, eğitim almayan annelerin ölçek puan ortalamalarından istatistiksel düzeyde anlamlı ölçüde yüksek olduğu belirlendi $(p=0,001)($ Tablo 5). Altundağ' ${ }^{(16)}$ aynı ölçek ile yapmış olduğu çalışmasında da benzer sonuçlara ulaşılmıştır. Ev içi güvenlik önlemlerinin arttırılmasında, sağlık personelinin birebir ev ziyaretlerinde bulunarak ev kazaları konusunda ebeveynlere eğitim vermesi ayrıca çeşitli basın-yayın organlarından ve eğitim araçlarından (broşür, kitapçık vb.) yararlanılarak bu konunun daha geniş toplumlara yayılması önerilebilir.

Kaza durumunda evde ilk müdahaleyi yapan kişi genellikle anne olduğu için annenin ilk yardım konusundaki bilgi, tutum ve davranışları çocuğun gelecekteki yaşamını da etkileyebilmektedir. Bu çalışma kapsamındaki annelerin, ilk yardım konusunda bilgi alma durumları ile ölçek puan ortalamaları arasinda istatistiksel düzeyde anlamlı bir ilişki olduğu belirlendi $(\mathrm{p}=0,002)$ (Tablo 5). Öztürk ve arkadaşlarının $(2010)^{(51)}$ yaptığ 1 araştırmada ise bu çalışmadan farklı olarak, annelerin ilk yardım konusunda bilgi alma durumları ile ölçek puan ortalamaları arasında bir ilişki olmadığı görülmüştür. Çeşitli kaza türlerinde yapılacak ilk yardım müdahaleleri ile bu kazaların nasıl meydana geldiğine dair bilgiler ilk yardımın konusunu oluşturmaktadır. Bu konularda bilgi sahibi olan annelerin, evde alınması gereken güvenlik önlemleri konusunda daha dikkatli davrandığı düşünülebilir.

Evinde ilk yardım çantası, yangın tüpü ve acil durum telefonların bulunduran anneler ile itfaiye ve ambulansın numarasinı bilen annelerin ölçek puan ortalamalarının istatistiksel düzeyde anlamlı ölçüde yüksek olduğu belirlendi $(\mathrm{p}<0,05)$ (Tablo 5). Evde yangın tüpü bulundur- mak ya da acil durum telefonların bilmek kazalara karşı bir tedbir olduğundan, tedbir alma eğiliminin kazalardan korunma bilinci gelişmiş kişilerde daha fazla olduğu söylenebilir.

Çocukluk çağı yaralanmalarında hemşirenin rolleri arasında; çevredeki tehlikeleri tanımlamak, azaltmak ve ortadan kaldırmak, çocuklardaki davranış özelliklerini tanımlamak ve çocuk gelişimi konusunda ebeveynlere rehberlik etmek yer almaktadır ${ }^{(17)}$. Hemşireler yaptıkları ev ziyaretleri ile kazaları değerlendirme, riskleri belirleme ve bu risk faktörlerinin azaltılmasına yönelik uygulamalar yapabilme firsatına sahiptirler ${ }^{54,55}$. Hemşireler ev kazaları konusunda halk1 uyararak üstlenmiş olduğu rolleri de (destekleyici, eğitici ve danışmanlık rolleri) yerine getirmiş olmaktadır ${ }^{36,56}$. Sağlık çalışanları, çocuk güvenliğinin danışmanları olarak çeşitli eğitim programları hazırlamalı, mevcut çalışmalara destek vermeli, çocuk hekimleri ve hemşireleri başta olmak üzere tüm sağlık çalışanları yaralanma kontrolü için yasal düzenlemelerin oluşturulmasında güçlü bir danışmanlık rolü üstlenmelidir.

\section{Kaynaklar}

1. Uğur Baysal S, Birinci A. Çocukluk Çağında Kazalar ve Yaralanma Kontrolü. Türkiye Klinikleri Journal Of Pediatrical Sciences, 2006; 2(2): 64-78.

2. Runyan CW, Casteel C, Perkis D, Black C, Marshall SW, Johnson RM, Coyne-Beasley T, Waller AE, Viswanathan S. Unintentional injuries in the home in the United States Part I: Mortality. American Journal of Preventive Medicine, 2005;28(1): 73-79.

3. Kendrick D, Coupland C, Mulvaney C, Simpson J, Smith SJ, Sutton A, Watson M, Woods A. Home safety education and provision of safety equipment for injury prevention. Cochrane Database of Systematic Reviews, 2007;1:Art. No.CD005014. DOI:10.1002/14651858.CD005014.pub2.

4. Potts NL, Mandleco BL. Pediatric nursing caring for children and their families. Delmor Company, USA, 2002; 14-17.

5. Bulut A, Gükçay G, Uğur Baysal S. Çocuk Sağlığı ve Hastalıkları. Sosyal Pediatri, Nobel Tip Kitapevi, İstanbul, 2003; 59-66.

6. Özcebe H. Yaralanma Kontrol ve Korunma Programları ve Güvenli Toplumlar. İçinde: Halk Sağlığı Temel Bilgiler. Eds: Güler Ç, Akın L. Hacettepe Üniversitesi Basımevi, Ankara, 2006; 685-698. 
7. Uskun E, Alptekin F, Öztürk M, Kişioğlu AN. The attitudes and behaviors of housewives in the prevention of domestic accidents and their first aid knowledge levels. Ulus Travma Acil Cerrahi Derg.,2008; 14(1): 46-52.

8. World Health Organization. News release, 10 December 2008| Geneva/ Hanoi/ New York Preventable injuries kill 2000 children every day. Erişim Tarihi: 20.06.2013. Erişim Adresi: http://www.who.int/mediacentre/news/releases/2008/pr46/en/print.html.

9. Sengoelge M, Bauer R, Laflamme L. Unintentional child home injury incidence and patterns in six countries in Europe. Int J Inj Contr Saf Promot, September, 2008;15(3): 129-139.

10. Hendrickson S G. Reaching an underserved population with a randomly assigned home safety intervention. Injury Prevention, 2005;11: 313-317.

11. Altundağ S, Öztürk MC. Ev kazaları nedeniyle hastaneye gelen 3-6 yaş grubu çocuklardaki kaza türleri ve bunu etkileyen etmenler. Çocuk Forumu, 2004; Mayıs- Ağustos, 5 : 60-64.

12. Özmen D, Ergin D, Şen N, Çetinkaya AÇ. 06 yaş grubu çocuğu olan annelerin ev kazalarına yönelik güvenlik önlemlerinin tanılanmas1. Aile ve Toplum Dergisi, Nisan-MayısHaziran, 2007;9: 3(12): 13-20.

13. Kıran S, Semin S, Ergör A. Kazalar ve Toplum Sağlı̆̆ı Yönünden Önemi. Sürekli Tip Eğitimi Dergisi(STED), 2001;10(2): 50-51.

14. Ulukol B, Şimşek F, Usubütün S, Gülnar S. 0-6 yaş grubu çocukların ev kazalarından korunmasında anne eğitiminin etkinliği. III. Ulusal Ana Çocuk Sağlı̆̆ Kongresi, İzmir, Bildiri Özet Kitab1, 2005; 255-257.

15. Çelik İnanç D, Uğur Baysal S, Ertem Vehid $\mathrm{H}$, Taviloğlu K. Epidemiologic and behavioral determinants in childhood injuries. ESSOP Annual Meeting, 16-18 October, Madrid, Abstract Book, 2003;134.

16. Altundağ S. Ev kazalarına yönelik eğitimin, güvenlik önlemleri alınması ve kaza görülme sıklığına etkisi. Dokuz Eylül Üniversitesi Sağlık Bilimleri Enstitüsü, Hemşirelik Yüksek Lisans Tezi, İzmir, 2005.

17. Brunner LS, Suddarth DS. Safety: Incidence of Childhood Accident. Pediatric Nursing. $3^{\text {rd }}$ ed. Lippincot Company, Philadelphia, 1982.
18. Çınar ND, Görak G. 0-6 yaş çocuklarda annenin ev kazalarına yönelik güvenlik önlemlerini tanılama ölçeğinin geliştirilmesi, geçerlik ve güvenirlik çalışması. Çocuk Forumu, 2003;6: 22-27

19. Alptekin F. Aksaray il merkezinde ev kazaları epidemiyolojisi, korumaya yönelik tutum ve davranışlar, ev kazalarına yönelik ilkyardım bilgi düzeyi. Süleyman Demirel Üniversitesi Sağlık Bilimleri Enstitüsü, Yüksek Lisans Tezi, Isparta, 2004.

20. Köse Ö, Bakırcı N. Çocuklarda ev kazaları. STED, 2007;16(3): 31-35.

21. Erkal S, Şafak Ş. Determination of the risks of domestic accidents for the 0-6 age group in the Tuzluçayır Village Clinic neighborhood. The Turkish Journal of Pediatrics, 2006; 48: 56-62.

22. Aktürk Ü, Erci B. 0-5 yaş grubu çocuğa sahip annelerin ev kazalarına neden olan faktörler ve önlemeye yönelik bilgi tutum ve davranışlarının saptanması. 15.Ulusal Halk Sağlı̆̆ Kongresi, Bursa, Bildiri Özet Kitab1, 2012; 863- 864.

23. Yalaki Z, Taşar MA, Kara N, Dallar Y. Sosyo-ekonomik düzeyi düşük olan ailelerin ev kazaları hakkında bilgi düzeylerinin ölçülmesi. Akademik Acil Tip Dergisi, 2010;9: 129-133.

24. Balibey M, Polat S, Ertem İ, Beyazova U, Şahin F. Çocukluk çağında ev kazalarına yol açan etmenler. Sürekli Tıp Eğitimi Dergisi, 2011;20(3): 89.

25. Dal Santo JA, Goodman RM, Glik D, Jackson K. Childhood unintentional injuries: factors predicting 1njury risk among preschoolers. Journal of Pediatric Psychology, 2004; 29(4): 273-283.

26. Alasya E. 1-6 yaş grubu çocuklarda ev kazası görülme sıklığ ve annelerin ev kazaları ile ilgili uygulamalarının belirlenmesi. Yakın Doğu Üniversitesi, Sağlik Bilimleri Enstitüsü, Hemşirelik Programı, Yüksek Lisans Tezi, Lefkoşe, 2012.

27. Del Ciampo LA, Ricco RG, De Almeida CA, Mucillo G. Incidence of childhood accidents determined in a study based on homöe surveys. Ann Trop Paediatr, 2001; 21(3): 239243

28. Çelik İnanç D, Uğur Baysal S, Coşgun L, Taviloğlu K, Ünüvar E. Çocukluk çağı yaralanmalarında hazırlayıcı nedenler. Türk Ped Arş, 2008; 43: 84-88. 
29. Chen LH, Gielen AC, McDonald EM. Validity of self reported home safety practices. Injury Prevention, 2003;9: 73-75.

30. Boztaş G. 0-48 aylık çocukların ev kazaları sonucu oluşan yaralanmalarına ilişkin annelerinin davranış ve görüşlerini etkileyen faktörlerin belirlenmesi. Hacettepe Üniversitesi Tıp Fakültesi Halk Sağlığ Uzmanlık Tezi, Ankara, 2008.

31. Tsoumakas K, Dousis E, Mavridi F, Gremou A, Matziou V. Parent's adherence to children's home-accident preventive measures. International Council of Nurses, 2009; 56(3): 369-374.

32. Aktaş B. 0-6 yaş grubu çocuğu olan annelerin ev kazalarına yönelik güvenlik önlemlerini tanilama durumu. STED, 2010;19(4): 146149.

33. Mahalakshmy T, Dongre AR, Kalaiselvan G. Epidemiology of childhood injuries in rural Puducherry, South India. Indian J Pediatr, 2011;78(7): 821-825.

34. Karatepe TU, Akış N. Nilüfer Halk Sağlığ Eğitim ve Araştırma Bölgesinde 0-6 yaş çocuklarda ev kazası geçirme sıklığı ve ilişkili faktörler.15. Ulusal Halk Sağlığı Kongresi, Bursa, Bildiri Özet Kitab1, 2012; 885-886.

35. Usubütün S, Karaoğlu L, Korkmaz Y, Güneş G. Malatya il merkezinde yaşayan 0-5 yaş arası çocuklarda ev kazası sıklığı ve etkileyen faktörler. 9. Ulusal Halk Sağlığı Günleri, Ankara, Bildiri Özet Kitabı, 2005;65.

36. Turan T, Ceylan SS. 0-6 yaş grubu çocukları olan annelerin ev kazalarını önlemek için aldıkları güvenlik önlemlerinin aile özelliklerine ve son bir aydaki ev kazaları sıklığına göre değerlendirilmesi. Sağlık ve Toplum, 2007;17 (4 ): 52-58.

37. Erkal S. Identification of the number of home accidens per year involving children in the 0 6 age group and the measures taken by mothers to prevent home accidets. Turkish Journal of Pediatrics, 2010; 52(2):150-157.

38. Atak N, Karaoğlu L, Korkmaz Y, Usubütün S. A household survey: unintentional injury frequency and related factors among children under five years in Malatya. Turk J Pediatr, 2010; 52: 285-293.

39. Çınar ND. 0-6 Yaş grubu çocukların ev kazalarından korunmasında ailenin rolü. Klinik Çocuk Forumu, 2004; 62-66.

40. Aksakal FNB, Çetin FE, Özdemirkan T, Tunca M Z, Aygün R. 0-6 yaş çocuğu olan ebeveynlerin ev kazaları konusunda bilgi, tutum ve davranışlarının saptanması. In 15. Ulusal Halk Sağlı̆̆l Kongresi. 2012.

41. Yıldırım N, Kublay G. 1-4 yaş dönemi çocukların ev kazası sıklığı ve risk faktörleri. 15. Ulusal Halk Sağllğı Kongresi, Bursa, Kongre Özet Kitab1, 2012; 865-867.

42. Altundağ S, Öztürk MC. Annelerin ev kazalarına yönelik güvenlik önlemleri alma konusundaki tutumların saptanmasi. III. Ulusal Ana Çocuk Sağlığı Kongresi, 22-24 Eylül, İzmir, Bildiri Özet Kitabı, 2005; 270.

43. Phelan K J, Khoury J, Xu Y, Lanphear B. Validation of a home injury survey. Injury Prevention, 2009;15(5): 300-306.

44. Theologos F, Nick D, Delia Marina A, Constantine F, George P, Melpomeni M, Eleni TP. Magnitude and object-specific hazards of aspiration and ingestion injuries among children in Greece. International Journal of Pediatric Otorhinolaryngology, 2007;71: 317-324.

45. Aşırdizer M, Yavuz MS, Albek E, Cantürk G. Infant and adolescent deaths in İstanbul due to home accidents. The Turkish Journal of Pediatrics, 2005; 47: 141-149.

46. Kim HB, Kim DK, Kwak YH, Shin SD, Song KJ, Lee SC, Park JO, Jang HY, Kim SC. Epidemiology of traumatic head injury in Korean children. J Korean Med Sci, 2012; 27 : 437-442.

47. Ademola AS, Dedeke IO, Oyelami OA. Childhood injuries in Ilesa, South-Western Nigeria: causes, pattern, and outcome. West Afr J Med, Jul- Aug., 2010;29(4): 253-258.

48. Erkal S, Şafak Ş. Tuzluçayır sağlık ocağı bölgesinde yaşayan ailelerde ev kazası görülme durumu ve konutların ev kazası riski açısından incelenmesi. Sağlik ve Toplum, NisanHaziran, 2003;96-100.

49. Chini F, Farchi S, Giorgi RP, Camilloni L, Borgia P, Guasticchi G. Road and home accident injuries of infants and adolescents in the Lazio region. Results of an integrated surveillance system. Epidemiol Prev, 2006;30 (4-5): 255-262.

50. Dericioğulları A, Konak Ş, Kılınç G, Orun Kavak H. 0-6 yaş grubu çocuğa sahip annelerin ev kazalarına yönelik güvenlik önlemlerini tanılama durumu. 5. Temel Sağlık Hizmetleri Sempozyumu, 2007; 65.

51. Öztürk C, Sarı H, Bektaş M, Elçigil A. Home accidents and mothers measurements in preschool children. Anatol J Clin Investig, 2010; 4(1): 15-21. 
52. Koştu N. 0-6 yaş grubunda çocuğu olan annelerin ev kazalarından çocuklarını korumaya yönelik aldıkları güvenlik önlemlerinin belirlenmesi. III. Ulusal Ana Çocuk Sağlığ Kongresi, 22-24 Eylül, İzmir, Bildiri Özet Kitab1, 2005; 282.

53. Yıldız Çiçekler C, Konuk Er R, Alakoç Pirpir D, Büyükbayraktar Ç. 0-6 yaş grubunda çocuğu olan annelerin ev kazalarına yönelik güvenlik önlemlerinin çeşitli değişkenlere göre incelenmesi. Ç.Ü. Sosyal Bilimler Enstitüsü Dergisi, 2012; 21(3): 157-174.

54. Smith CM. Home Visit: Opening the Doors for Family Health. In: Community / Public Health Nursing Practice: Health for Families and Populations. Eds: Maurer FA, Smith CM. $4^{\text {th }}$ ed. Saunders Elsevier, United States, 2009; 302-321.

55. Turan T, Dündar AS, Yorgancı M, Yıldırım Z. 0-6 yaş grubu çocuklarda ev kazalarının önlenmesi. Ulusal Travma ve Acil Cerrahi Dergisi, 2010;16 (6): 552-557.

56. Çalışkan K, Avcı Ö, Acar V, Candan Dönmez Y. 0-6 yaş grubu çocuğu olan annelerin düşmelere ilişkin ilkyardım ugulamalarının incelenmesi. Maltepe Üniversitesi Hemşirelik Bilim ve Sanat1 Dergisi, 2010;3(3): 2-8.

57. Carls C. The prevalence of stress urinary incontinence in high school and college-age female athletes in the Midwest: implications for education and prevention. Urol Nurs 2007;27:21-24.

58. 39. Song Y F, Zhang WJ, Song J, et al. Prevalence and risk factors of urinary incontinence in Fuzhou Chinese women. Chinese Med J 2005;118:887-892.

59. Eliasson K, Nordlander I, Larson B, et al. Influence of physical activity on urinary leakage in primiparous women. Scand J Med Sci Sports 2005;15:87-94.

60. Nygaard IE. Does prolonged high-impact activity contribute to later urinary incontinence? A retrospective cohort study of female olympians. Obstet Gynecol 1997;90:718-722.

61. Coyne KS, Cash B, Kopp Z, Gelhorn H, Milsom I, Berriman S, Vats V, Khullar V. The prevalence of chronic constipation and faecal incontinence among men and women with symptoms of overactive bladder. BJU Int. 2011;107(2):254- 261.

62. Kaplan SA, Dmochowski R, Cash BD, Kopp ZS, Berriman SJ, Khullar V. Systematic review of the relationship between bladder and bowel function: implications for patient management. International Journal of Clinical Practice 2013;67(3):205-216. 